\title{
Nanosized Minicells Generated by Lactic Acid Bacteria for Drug Delivery
}

\author{
Huu Ngoc Nguyen, ${ }^{1}$ Santa Romero Jovel, ${ }^{2}$ and Tu Hoang Khue Nguyen ${ }^{1}$ \\ ${ }^{1}$ School of Biotechnology, International University, Vietnam National University, Hochiminh City, Quarter 6, Linh Trung Ward, \\ Thu Duc District, Hochiminh City, Vietnam \\ ${ }^{2}$ National Scientific Research Center of El Salvador, Alameda Juan Pablo II y Calle Guadalupe, Plan Maestro Edif. A4, \\ 3er Nivel DNICTI, San Salvador, El Salvador \\ Correspondence should be addressed to Tu Hoang Khue Nguyen; nhktu@hcmiu.edu.vn
}

Received 4 May 2017; Accepted 25 July 2017; Published 7 September 2017

Academic Editor: Sohel Rana

Copyright (C) 2017 Huu Ngoc Nguyen et al. This is an open access article distributed under the Creative Commons Attribution License, which permits unrestricted use, distribution, and reproduction in any medium, provided the original work is properly cited.

\begin{abstract}
Nanotechnology has the ability to target specific areas of the body, controlling the drug release and significantly increasing the bioavailability of active compounds. Organic and inorganic nanoparticles have been developed for drug delivery systems. Many delivery systems are through clinical stages for development and market. Minicell, a nanosized cell generated by bacteria, is a potential particle for drug delivery because of its size, safety, and biodegradability. Minicells produced by bacteria could drive therapeutic agents against cancer, microbial infection, and other diseases by targeting. In addition, minicells generated by lactic acid bacteria being probiotics are more interesting than others because of their benefits like safety, immunological improvement, and biodegradation. This review aims to highlight the stages of development of nanoparticle for drug delivery and discuss their advantages and limitations to clarify minicells as a new opportunity for the development of potential nanoparticle for drug delivery.
\end{abstract}

\section{Introduction}

There are many researches concentrating on the ways of delivering drugs directly to tumor tissue. Drug delivery undergoes many stages consisting of entering the body, passing through the blood-stream to cancerous cells $[1,2]$. Furthermore, drug delivery system is developed to achieve a higher degree of tumor cell specificity and reduce side effects. However, nanoparticle could also accumulate in the liver and the spleen, where they provide no therapeutic benefit and can cause side effects $[3,4]$. To minimize unwanted effects, researchers developed biodegradable materials. The first biodegradable nanoparticles to be developed for drug delivery coated the active agent with lipids [5]. The first drug of this type to be approved was Doxil in 1995 [6]. According to the US National Cancer Institute, six nanoparticles are currently approved for use on the market worldwide, while these costs of products were higher ten times than conventional treatment $[7,8]$.

Recently, using bacterially derived nanosized particles to package a range of different chemotherapeutic drugs is a new technology that is specifically targeting the minicells to tumor cell surface receptors via bispecific antibodies coating the minicells. Minicells loading drugs could have effect on the apoptosis of tumor cells both in vitro and in vivo. They also targeted cancer cells in vivo with high specificity and effectivity without toxicity [9].

The minicells are generated from mutant bacteria and kept their cell membrane structure. The minicells could load chemicals as anticancer drugs and are coated with antibodies to bind the specific receptors on the surface. The cancer cells recognize the bacterial minicells and then swallow these minicells with cancer killing drug. In previous study for phase I, minicells were loaded with a cytotoxic chemotherapy drug called paclitaxel and coated with an antibody targeting tumors expressing the epidermal growth factor receptor (EGFR) for treating small groups of patients $[10,11]$.

The purpose of this review was to discuss the positive and negative effects of nanotechnology for drug delivery and propose novel biodegradable nanocells originating from lactic acid bacteria due to their benefits. 


\section{General Nanoparticle}

Nanotechnology was first defined in 1974 by Norio Taniguchi that is the engineering technology for understanding and control of matter at the length scale of approximately 1 to 100 nanometers [1]. Numerous nanomaterials preparations have been potentially applied for drug delivery system to therapeutics. Several nanosized preparations such as liposomes, polymeric micelles, and polymeric-drug conjugates have been developed in vitro, while others undertake preclinical studies [12, 13]. Besides, some successful nanosized preparations have already emerged in today's pharmaceutical market and showed better clinical performance than traditional drugs $[14,15]$. The properties including size, surface charge, shape, and density of surface associated ligands can allow nanoparticles to avoid renal clearance but reach the designated cellular destinations in sufficient amounts, eliciting a biological response with minimal nonspecific interactions [16].

Nanoparticles are the best drug delivery systems that can be administered via intravenous injection or other routes based on their sizes [17]. The materials for nanoparticle preparation are not only biological like lactic acid, dextran, phospholipids, lipids, carbon, and chitosan but also chemical like polymers, silica, and metals [18-21]. Each nanoparticle had a special property in drug delivery. Even though solid nanoparticles may be used for drug targeting, the delivered drug must escape after reaching the target. Therefore, nanoparticle should be structured well to let the drug be released effectively.

Currently, there are several products already available on the market, while many others are in the preclinicalto-clinical pipeline. The major interest in cancer therapy is also reflected in an important industry. Some currently marketed nanotherapeutics in cancer therapy are liposomes, nanoparticles, nanocapsules, nanoemulsions, nanocrystals, and micelles [22-26]. However, nanomedicines currently approved for cancer therapy are mostly liposomes. Other products are in advanced clinical trials. Several others are at earlier stages of clinical trials or in preclinical phase.

Over the last years, the importance of bridging together nanotechnology and cancer therapy has been realized. The National Cancer Institute (NCI) in US has created the NCI Alliance for Nanotechnology in Cancer [27, 28] and the European Science Foundation has also issued a report in analyzing the situation of nanomedicine in Europe [29, 30]. They have designated nanotechnology and its applications to biomedicine as one of its major priority research areas.

\section{Advantage of Nanomedicine}

Targeted drug delivery system is developed to achieve a higher degree of tumor cell specificity but also reduces side effects. Active targeting of nanoparticles is the merging of target sections such as ligands or antibodies on the surface of nanocarriers to specific receptors on the tumor cells and endothelium shown on Figure 1 [31-34]. The active targeting increases the selectivity of the drug delivery. Furthermore,

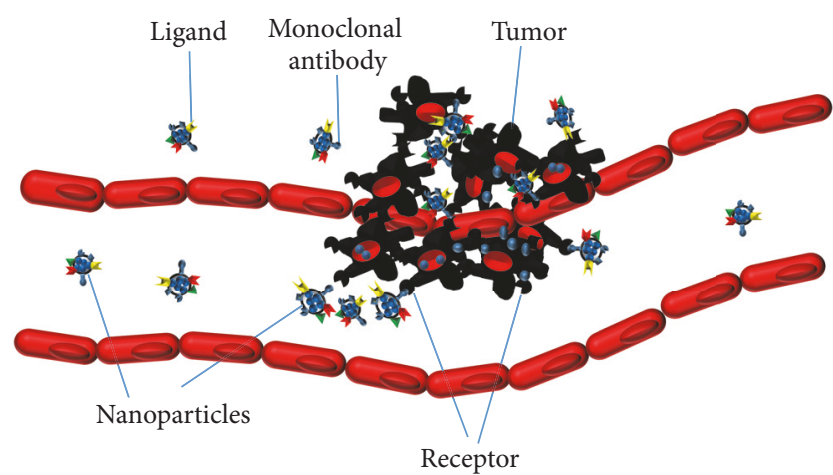

FIGURE 1: Nanoparticles coated with monoclonal antibody for specific activity.

nanocarriers have a high surface area allowing for multiple ligands to combine on their surfaces to direct cells and have some drawbacks $[35,36]$. Nanoparticles combined with ligands to reduce toxicity due to avoiding the nonspecific binding and then decrease multidrug resistance in tumor cells as well [37].

Based on the expression of receptors or epitopes on the cell surface, nanoparticles could bind to target cells through ligand receptor interaction. Internalization of targeting conjugates can also occur by receptor-mediated endocytosis after binding to target cells; then drug will be released inside the cells (Figure 2) [38, 39]. The conjugates bind with their receptors, followed by plasma membrane enclosure around the ligand receptor complex to form an endosome based on the receptor-mediated endocytosis mechanism. The newly formed endosome is transferred to specific organelles where drug was released by acidic $\mathrm{pH}$ or enzymes [40].

On the other hand, nanoparticle used to improve a drug formulation could be served as an alternative to conventional administration vehicles, which are sometimes toxic; for example, the potent chemotherapeutic paclitaxel is not soluble in water. Under the trade name as Taxol ${ }^{\circledR}$, paclitaxel is dissolved in cremophor EL, a polyoxyethylated castor oil, which is toxic. Abraxane ${ }^{\circledR}$, an albumin-bound form of paclitaxel, uses the nanotech platform of albumin as an alternative to cremophor EL. Abraxane has been shown to be both more efficacious and less toxic than Taxol [41, 42].

3.1. The Increase of Drug Stability. Many drugs used in anticancer therapy are unstable even under mild conditions. Low molecular weight drugs suffer degradation by diverse mechanisms as photochemical reactions, oxidation, hydrolysis, and so on [43]. Polypeptide drugs can be partially denatured during storage and lose their activities. Nanocarriers can increase the stability of many anticancer drugs by integrating them into their structure. For instance, doxorubicin is quickly degraded upon exposure to light, whereas doxorubicin entrapped into nanoparticles maintains its biological activity under the same conditions [44]. The stability of doxorubicin has also been increased through its incorporation into liposomes [45]. In the same way, paclitaxel 


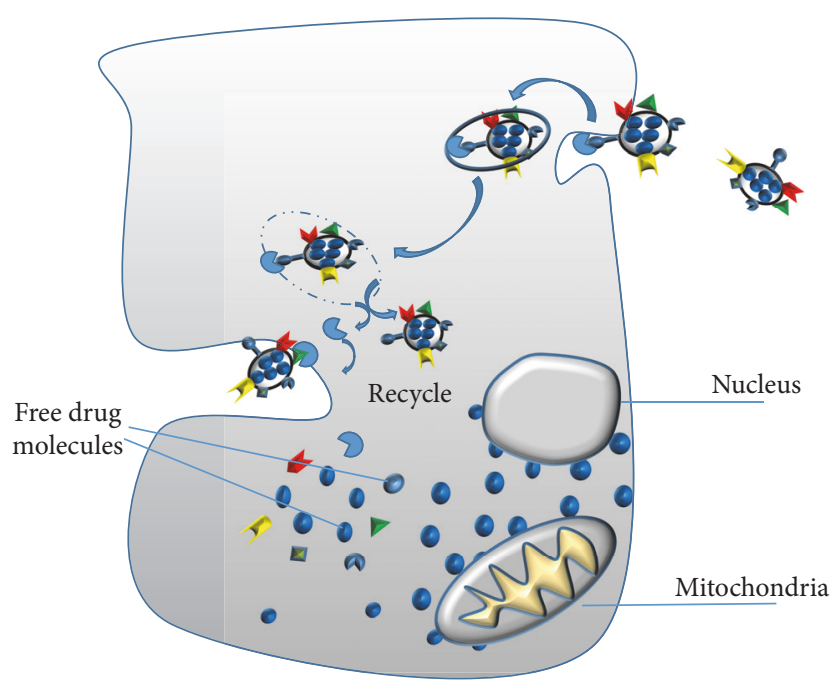

FIGURE 2: Schematic drawing of the drug release and organellespecific targeting of drug loaded nanoparticles via endocytosis.

used for the antineoplastic treatment was formulated in a surfactant/alcohol mixture and increased the shelf-life to 71 days at $25^{\circ} \mathrm{C}$, and its stability is reduced even further upon dilution [46, 47]. Previous study reported a beneficial effect on long-term DNA stability when this molecule was complexed to polymeric micelles [48, 49].

\subsection{The Improvement of Drug Administration and Absorption}

3.2.1. Oral Administration. In general terms, anticancer drugs have low oral bioavailability. For large macromolecules, this is related to their fast enzymatic degradation and their inefficiency in crossing biological barriers [50, 51]. For hydrophobic drugs, their main limitation is their low solubility at the absorption site, but also their biodegradation. The case of many conventional hydrophobic drugs is finely illustrated by paclitaxel $[52,53]$. This molecule has low oral bioavailability in conventional formulations because most of the drug is eliminated through the cytochrome P450dependent metabolism and excreted by the P-glycoprotein pump present in the intestinal wall [54-56]. Nanosystems may improve drug absorption in oral chemotherapy by protecting the drug, enhancing its residence time at the absorption site or through the inhibition of efflux pumps. Previous studies reported that new $\mathrm{d}$ - $\alpha$-tocopheryl-PEG succinate nanoparticles could be used for oral delivery of paclitaxel [57-59]. On the other hand, liposomes formed by a blend of collagen and carrageenan polymeric core were also found to enhance the permeability of 5-fluorouracil (5-FU) and methotrexate crossing the Caco- 2 and TC7 monolayers [23].

3.2.2. Parenteral Administration. Parenteral formulations have the additional advantage of drug absorption. However, the preparation of injectable formulations of many hydrophobic drugs is very low water solubility. Indeed, intravenous injection of these drugs may cause embolization of blood vessels due to drug aggregation, and ultimately, local toxicity as a result of high drug concentrations at the site of deposition $[60,61]$. Cremophor EL (Taxol) has been the standard solvent system for paclitaxel including clinically relevant acute hypersensitivity reactions and peripheral neuropathy [62]. Moreover, paclitaxel-loaded albumin nanoparticles (Abraxane or ABI-007) have recently been approved by FDA for the treatment of metastatic breast cancer [23].

3.3. Increase in Blood Circulation. Changes in drug biodistribution and accumulation in the target tissues can be achieved through the incorporation of these drugs into specific nanocarriers. Classical nonselective nanocarriers are known to be opsonized and rapidly cleared by the mononuclear phagocytic systems (MPS) which is predominantly distributed in liver, lungs, spleen, and bone marrow [23, 63]. This uptake can be very advantageous for the chemotherapeutic treatment of MPS-localized tumors like hepatocarcinoma or hepatic metastasis. This therapeutic benefit has been observed with doxorubicin in a murine hepatic metastases model when this drug was incorporated into biodegradable poly(alkylcyanoacrylate) nanoparticles [64-66]. Polyethylglycol has been applied to enhance the plasmatic half-life of several nanocarriers including liposomes and micelles [6769].

3.4. Active Targeting to the Cancer Cells. Nanomedicine designed to actively target cancer cells showed high binding affinity to its receptor on cancer cells. Specific monoclonal antibodies were able to bind to corresponding tumor antigens $[12,70,71]$. At present, there are several formulations comprising antibodies approved or undergoing clinical trials. For example, Mylotarg ${ }^{\circledR}$ conjugated with CD33 antibody and Zevalin ${ }^{\circledR}$ and Bexxar ${ }^{\circledR}$ conjugated with two CD20 have already been approved by the FDA [72]. A liposome-plasmid DNA formulation (SGT-53) that uses an antibody fragment for tumor targeting is currently in phase I clinical trial $[23,73]$. The other work reported that there were encapsulated antineoplastic drugs in bacterially derived nanosized delivery system linked with antibodies to the target [74]. Actively targeted minicells resulted in antitumor effects enhanced efficacy even compared to other less sophisticated nanomedicines.

\section{Challenges of Nanoparticles}

However, there are limited reports about the effects of nanoparticles on the body. It is difficult to predict the longterms effects on our health. Nanoparticles have large surface that helps them react very quick [75]. A metal nanoparticle is an example that they might speed up reactions in living things in unpredictable ways causing illness or death [75, 76]. Furthermore, nanoparticles have ability in antimicrobial activities but also they may kill benefit bacterial communities in the intestinal tract. Besides, there are chemicals or physical systems applied to maintain them to retain their nanoscale properties because nanoparticles are easy to aggregate or club together $[77,78]$. 
In addition, drug delivery system in nanoparticles is more expensive to produce when compared with traditional materials due to containing lots of complicated steps [19, 79]. Therefore, it is a difficult to scale up nanoparticle production leading to limitation in market production. More importantly, the human immune system may be defenseless against particles on the nanoscale [80-82]. As a result, tiny solid particles can cause irritation in the lungs and potentially cause lung damage and cancer. In summary, nanoparticles are usually reported in a positive way because of their exciting potential applications in drug delivery. However, a nanoparticle is also a risk due to their unknown side effects and bioavailability that have not been reported yet [18, 83-87].

Nanoparticles used as drug delivery are more and more popular with a lot of challenges in pharmaceutical engineering. There are many reports about nanotoxicology, the potential negative impact of the interactions between nanomaterials and biological systems. For example, naked quantum dots show cytotoxicity by induction of reactive oxygen species, resulting in damage to the nucleus, mitochondria, and plasma membranes $[18,88]$. Furthermore, cadmium(Cd-) containing quantum dots have been reported to be toxic due to the release of free $\mathrm{Cd}^{2+}$ ions [89, 90]. Gold $\mathrm{Au})$ solution has not been considered to present a hazard, and gold nanoparticles (Au NPs) have been taken up by cells without cytotoxic effects [91, 92]. By contrast, gold nanorod cytotoxicity could be attributed to the presence of the stabilizer cetyltrimethylammonium bromide [93, 94]. For silica nanoparticles (NPs), only concentrations over $0.1 \mathrm{mg} / \mathrm{ml}$ were found to be toxic as shown in a reduction of cell availability and proliferation $[18,94]$. The production of carbon nanotubes also causes reactive oxygen species generation, mitochondria dysfunction, lipid peroxidation, and changes in cell morphology, while graphite and fullerene produce no significant adverse effects $[18,95,96]$. In addition, it was reported that most cationic NPs can cause hemolysis and blood clotting, while neutral and anionic NPs are quite nontoxic [40, 97].

Another challenge facing nanosized drug delivery is the large scale production of nanomaterials in terms of scaling up laboratory or pilot technologies for commercialization. A number of nanosized drug delivery technologies may not be compatible with large scale production due to the nature of the preparation method and high cost of materials [98]. The challenges of scaling up include a low concentration of nanomaterials, agglomeration, and the chemistry process [99-101].

Generally, most drugs do not cross the blood brain barrier (BBB). The endothelial barrier is specifically tight at the interface with the brain astrocytes and can be in normal conditions only being passed using endogenous BBB transport or receptor-mediated transport [18, 102, 103]. However, the barrier properties may be compromised intentionally or unintentionally by drug treatment allowing passage of nanoparticles [104-107]. The drugs delivered by nanocarrier to pass through blood brain barrier were recently reviewed $[108,109]$.

\section{Nanosized Delivery Generated by Microorganisms}

Minicells are one of nanoparticles generated from bacteria that can deliver active compounds to reduce the side effects and improve bioavailability of the treatment [110]. Minicells are chromosomal cells containing RNA and protein but little or without chromosomal DNA. There are lots of applications of minicells reported as delivery for therapeutics, nucleic acids, and other bioactive compounds to target cells. MacDiarmid introduced minicells generated by Shigella flexneri, Pseudomonas aeruginosa, Salmonella typhimurium, Escherichia coli, and Listeria monocytogenes with diameter about $400 \mathrm{~nm}$ [9]. In addition, Lactobacillus rhamnosus and Lactobacillus acidophilus could generate minicells with nanosize as well [111-113].

During the cell division cycle, the cells must identify the mid-cell site prepared for cytokinesis and division septum (Figure 3). For example, the mutants in E. coli were divided into two group, fts mutants (temperature sensitive filamentation) and par mutants (partition). There are many important proteins involved in the division cycle. FtsZ is one of proteins that play a significant role in the division process of E. coli $[114,115]$. In previous report, MacDiarmid and colleagues described bacterial minicells encapsulated chemotherapeutics guided by antibodies to deliver their load to target cells. Minicells have diameter of $400 \mathrm{~nm}$ produced from both Gram-positive and Gram-negative bacteria. Furthermore, the minicells were loaded with different chemotherapeutics in hydrophobic and hydrophilic forms. Besides, minicells could lead to the targeted tumor cells with bispecific antibodies of epidermal growth factor receptor (EGFR), HER2/neu (ERBB2), CD33, or CD3 [116-118].

Minicell formation related to cell division inhibitor genes of fts $Z$, minBCD locus causing asymmetrical division at midcell leading to cells of different sizes including minicells as well as filaments. The minicells were isolated and showed the stable round shape. Minicells keep the rigid cell wall structure of 20 kinds of lipopolysaccharide like their parental bacteria [119]. The pathogen strains could produce minicells applied to vaccine but not complete safe for patient compared to lactic acid bacteria strains [120]. Therefore, minicells generated by lactic acid bacteria that are probiotic strain should be more interesting than others.

The Gram-positive cell wall of lactic acid bacteria consists mainly of peptidoglycans, (lipo)teichoic acids, proteins, and polysaccharides [121]. The inner layer of the cell wall consists of a peptidoglycan network covered by a variety of substances. The most important of these substances are (lipo)teichoic acids, neutral and acidic polysaccharides, and surface proteins [122]. Teichoic acids are the negative charged polymers constituted with polyol phosphate that linked to the peptidoglycan $[122,123]$.

The polysaccharides associated with the bacterial cell walls and the extracellular polysaccharides of lactic acid bacteria are either neutral or acidic $[120,121]$. There are abundance polysaccharides at the outer surface of the cell wall and extracellular. The most abundant surface proteins in many Lactobacillus species are the S-layer proteins [122, 124, 125]. 


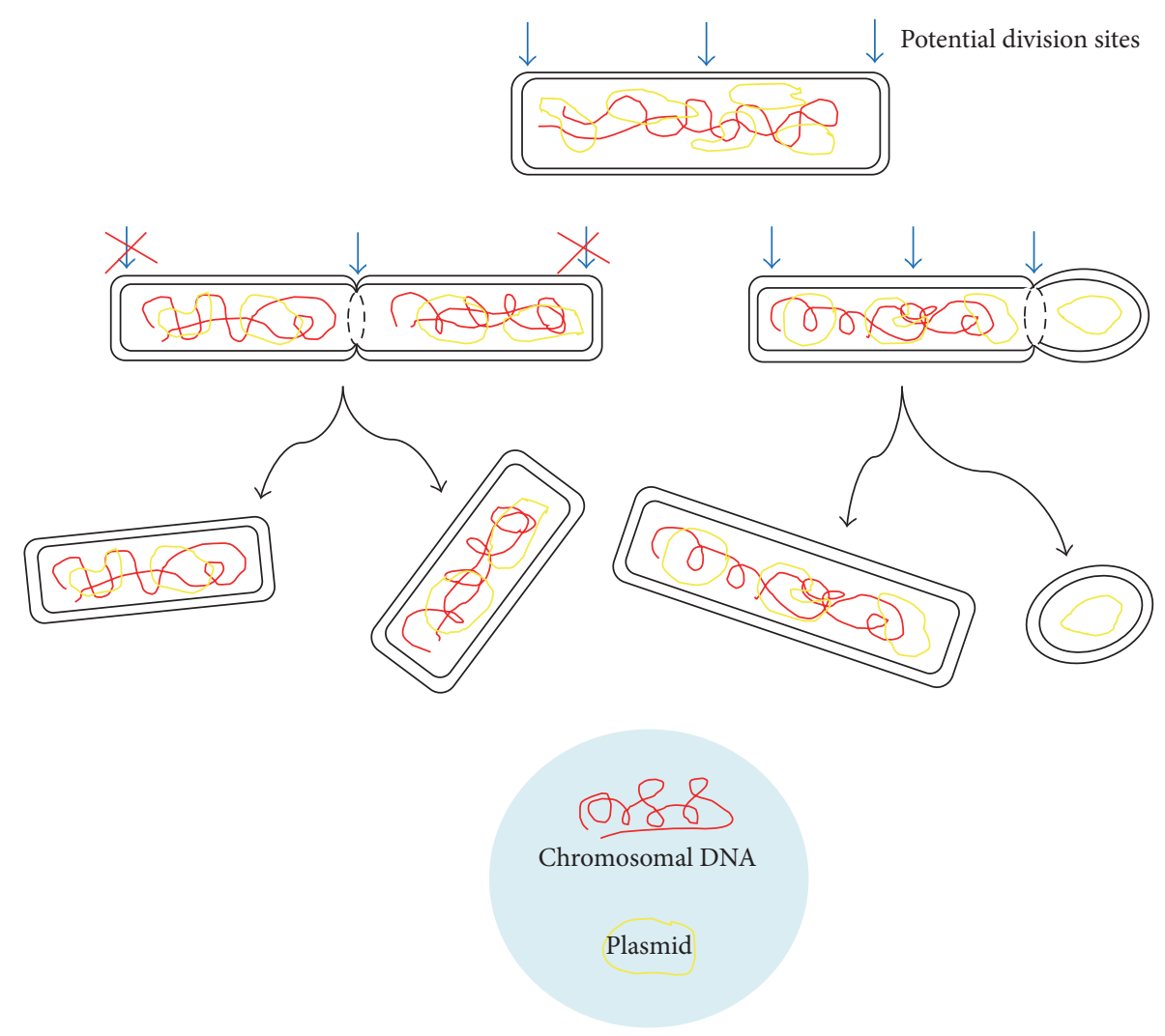

FIGURE 3: Bacterial minicell formation.

To date, S-layers have been found in L. brevis, L. acidophilus, L. crispatus, L. helveticus, L. amylovorus, and L. gallinarum. S-layer proteins are usually small proteins of 40-60 kDa with generally highly stable tertiary structures [126]. L. rhamnosus and L. acidophilus in combination with glucose and fructose occurred to produce the highest minicells with the size less than $400 \mathrm{~nm}$ that could be used as nanocells in delivering cisplatin, paclitaxel, and cephalosporin [111-113].

\section{Minicell Loading with Different Drugs}

Interestingly, minicells can be packaged with 1-10 million drug molecules [18]. Minicells pass through tumor cells by receptor-mediated endocytosis. In in vivo experiments, doxorubicin loading minicells inhibited tumor growth in mice as breast, ovarian, leukemia, or lung [127]. Importantly, comparatively small amounts of doxorubicin could induce tumor regression in liposome encapsulation. The anticancer efficacy of the minicells was further evaluated in dogs having T-cell non-Hodgkin's lymphoma by tumor regression and tumor lysis [116]. Importantly, many researches showed that minicells did not have side effects such as proinflammatory cytokine increase after repeating the doses. Other experiments in animals were also performed and pointed that there were no adverse reactions [128]. Minicells derived from bacteria have been used for the first time in human with the significantly safe, well-tolerated results. Solomon et al. reported that minicells packaged paclitaxel and coated with antibody targeting to tumors expressing EGFR of many
TABLE 1: Functional groups detected in bacteria.

\begin{tabular}{lc}
\hline $\begin{array}{l}\text { Functional } \\
\text { group }\end{array}$ & $\begin{array}{c}\text { Interaction or reaction } \\
\text { Hydroxyl }\end{array}$ \\
Carboxyl & $\begin{array}{c}\text { Carbonyl, aromatic, alkyl groups or } \\
\text { a carbon atom }\end{array}$ \\
Phosphoryl & Acid-base \\
Amide & Group transfer \\
Phosphate & Acid-base \\
Carbohydrate & Acid-base \\
\hline
\end{tabular}

cancer cells. The study was then conducted in phase I with small groups of patients. Minicells loaded with doxorubicin were also continuously tested in phase II in patients with glioblastoma (a type of brain tumor) [128, 129].

However, Lactobacillus species being the safe microorganisms with many biological activities in anticancer and immunotherapy, they were used to generate nanosized minicells tested in drug delivery. Due to living cells, Lactobacillus minicells are the place of different reactions. Therefore, minicells containing a variety of functional groups mentioned in Table 1 can bind with different compounds easily when they meet together. Minicells from Lactobacillus could show their own activities and load with hydrophilic and hydrophobic drugs as well, for example, paclitaxel and cephalosporin (Figure 4) [111]. Hydrogen bond in minicells could help 


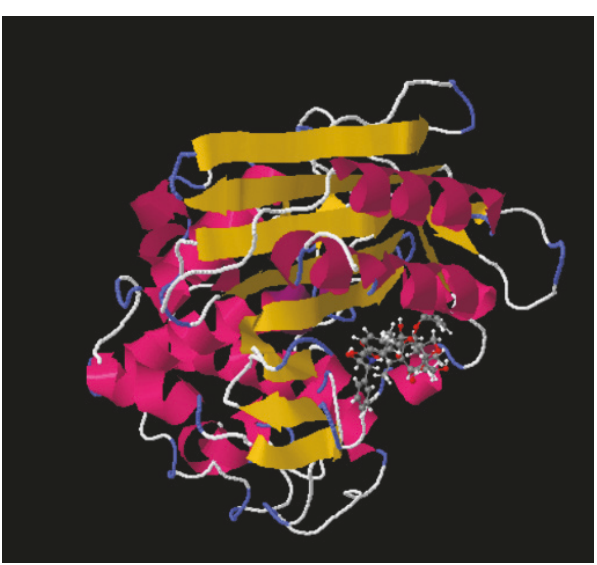

(a)

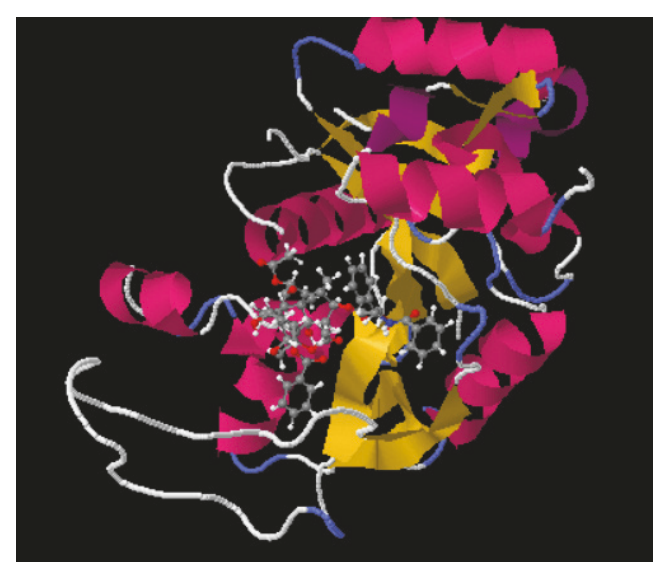

(b)

FIGURE 4: The interaction between minicell membrane and molecule. (a) Interaction between teichoic acid and paclitaxel. (b) Interaction between dd-transpeptidase and paclitaxel.

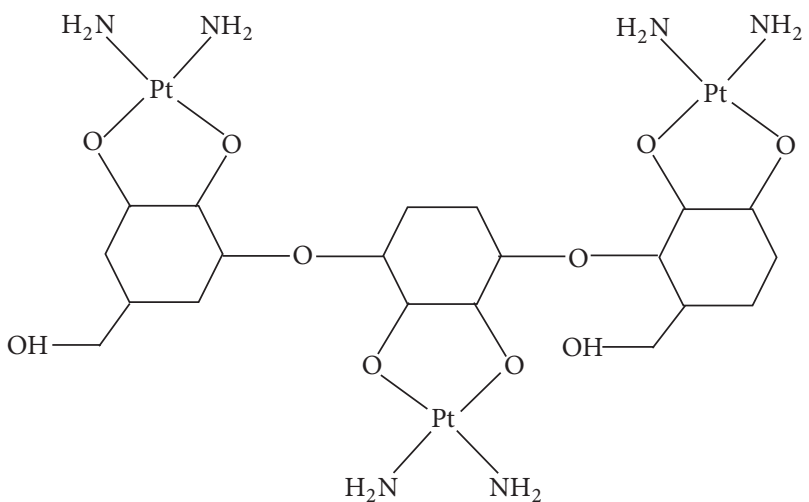

FIGURE 5: Model of exopolysaccharide representative in the interaction with cisplatin.

in loading drug molecules. Using docking to explain the interaction of drug to minicells, paclitaxel binds to ddtranspeptidase and teichoic acid of minicell membrane by the interaction with many residues by hydrogen bonds. The average binding energy is -7 to -10 . In the other illustration for drug loading of minicells, exopolysaccharide could bind to cisplatin as presented in Figure 5. With the interaction, cisplatin could be released out of minicells to show activities. Moreover, minicells have the cell walls that make many drugs pass through by concentration gradient. Generally, the model of drug loading was showed as in Figure 6.

\section{Minicells Avoid Phagocytosis}

There were many arguments that minicells used in treatment could be phagocytosed. However, by experiments, minicells could go inside and outside the macrophages. They can be stable in about 6 hours. Actually, minicells loaded doxorubicin could be used in trials and treat cancer in the volunteers. Remarkably, minicells can be an ideal drug delivery because of safety, biodegradability, and avoiding

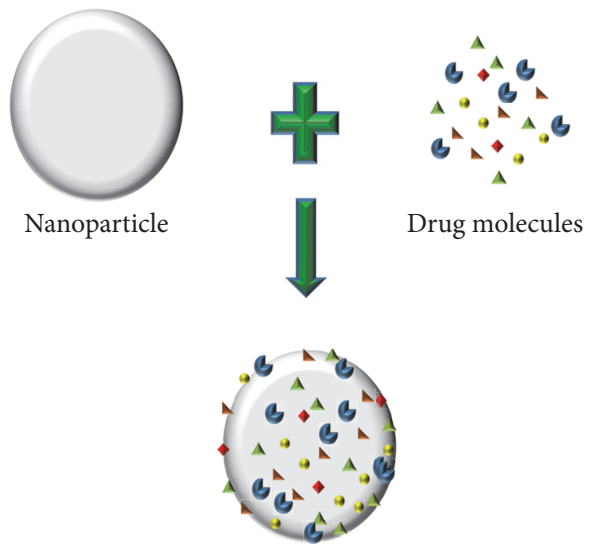

Figure 6: The model of drug molecules loaded by minicells.

of phagocytosis. Minicells produced from L. acidophilus in sugar stress remained stable in storage at $-80^{\circ} \mathrm{C}$ for long time.

\section{Conclusions}

The nanoparticle development for drug delivery is interesting in therapy. The majority of properties of minicells generated by lactic acid bacteria are nanosized, round shape which is suitable for drug delivery. Multifunctional nanoparticles delivering multiple drugs are now being developed for enhanced detection and treatment of cancer. Furthermore, lactic acid bacteria are used in pharmaceutical field and food industry. Minicells generated by lactic acid bacteria are a biodegradable system which is excellent vehicle for delivery of drugs and vaccines. The application of minicells to cancer has a great promise for cancer patients in the future.

\section{Abbreviations}

EGFR: Epidermal growth factor receptor MPS: Mononuclear phagocytic systems. 


\section{Conflicts of Interest}

There are no conflicts of interest in all authors regarding the publication of this paper.

\section{References}

[1] R. E. Serda, B. Godin, E. Blanco, C. Chiappini, and M. Ferrari, "Multi-stage delivery nano-particle systems for therapeutic applications," Biochimica et Biophysica Acta - General Subjects, vol. 1810, no. 3, pp. 317-329, 2011.

[2] J. Wright, "Nanotechnology: Deliver on a promise," Scientific American, vol. 311, no. 1, pp. S12-S13, 2014.

[3] M. E. Davis and D. M. Shin, "Nanoparticle therapeutics: an emerging treatment modality for cancer," Rev Drug Discov, vol. 7, pp. 771-782, 2008.

[4] V. J. Mohanraj and Y. Chen, "Nanoparticles-a review," Trop J Pharm Res, vol. 5, pp. 561-573, 2006.

[5] J. Panyam and V. Labhasetwar, "Biodegradable nanoparticles for drug and gene delivery to cells and tissue," Advanced Drug Delivery Reviews, vol. 55, no. 3, pp. 329-347, 2003.

[6] Y. Barenholz, "Doxil: the first FDA-approved nano-drug: lessons learned," Journal of Controlled Release, vol. 160, no. 2, pp. 117-134, 2012.

[7] G. Pillai, "Nanomedicines for Cancer Therapy: An Update of FDA Approved and Those under Various Stages of Development," SOJ Pharmacy \& Pharmaceutical Sciences, vol. 1, no. 2, 2014.

[8] V. Weissig, T. K. Pettinger, and N. Murdock, "Nanopharmaceuticals (part 1): products on the market," International journal of nanomedicine, vol. 9, pp. 4357-4373, 2014.

[9] J. A. MacDiarmid, N. B. Mugridge, J. C. Weiss et al., "Bacterially Derived $400 \mathrm{~nm}$ particles for encapsulation and cancer cell targeting of chemotherapeutics," Cancer Cell, vol. 11, no. 5, pp. 431-445, 2007.

[10] D. Gastaldi, D. Zonari, and F. Dosio, "Targeted taxane delivery systems: recent advances," Deliv Lett, pp. 105-117, 2011.

[11] Y. D. Livney and Y. G. Assaraf, "Rationally designed nanovehicles to overcome cancer chemoresistance," Advanced Drug Delivery Reviews, vol. 65, no. 13-14, pp. 1716-1730, 2013.

[12] R. Gaspar and R. Duncan, "Polymeric carriers: preclinical safety and the regulatory implications for design and development of polymer therapeutics," Drug Deliv Rev, vol. 61, pp. 1220-1231, 2009.

[13] R. Duncan and M. J. Vicent, "Do HPMA copolymer conjugates have a future as clinically useful nanomedicines? a critical overview of current status and future opportunities," Drug Deliv Rev, vol. 62, pp. 272-282, 2010.

[14] R. Duncan, "Polymer therapeutics: top 10 selling pharmaceuticals-what next?" Journal of Controlled Release, vol. 190, pp. 371-380, 2014.

[15] J. Miller, "Beyond biotechnology: FDA regulation of nanomedicine," Sci Technol Law Rev, 2003.

[16] S. Biswas and V. P. Torchilin, "Nanopreparations for organellespecific delivery in cancer," Advanced Drug Delivery Reviews, vol. 66, pp. 26-41, 2014.

[17] L. Brannon-Peppas and J. O. Blanchette, "Nanoparticle and targeted systems for cancer therapy," Drug Deliv Rev, vol. 64, 2012.

[18] W. H. De Jong and P. J. Borm, "Drug delivery and nanoparticles: applications and hazards," Int J Nanomedicine, vol. 3, pp. 133149, 2008.
[19] R. Singh and J. W. Lillard, "Nanoparticle-based targeted drug delivery," Exp Mol Pathol, vol. 86, pp. 215-223, 2009.

[20] N. T. Thanh and L. A. Green, "Functionalisation of nanoparticles for biomedical applications," Nano Today, vol. 5, pp. 213$230,2010$.

[21] M. Athar and A. J. Das, "Therapeutic nanoparticles: state-ofthe-art of nanomedicine," Ad Mater Rev, vol. 1, pp. 25-37, 2014.

[22] A. Hafner, J. Lovrić, G. P. Lakǒ, and I. Pepić, "Nanotherapeutics in the EU: An overview on current state and future directions," International Journal of Nanomedicine, vol. 9, no. 1, article no. 1005, pp. 1005-1023, 2014.

[23] P. Hervella, V. Lozano, M. Garcia-Fuentes, and M. J. Alonso, "Nanomedicine, new challenges and opportunities in cancer therapy," J Biomed Nanotechnol, vol. 4, pp. 276-292, 2008.

[24] C. M. J. Hu, S. Aryal, and L. Zhang, "Nanoparticle-assisted combination therapies for effective cancer treatment," Ther Deliv, vol. 1, pp. 323-334, 2010.

[25] M. L. Etheridge, S. A. Campbell, A. G. Erdman, C. L. Haynes, S. $\mathrm{M}$. Wolf, and J. McCullough, "The big picture on nanomedicine: the state of investigational and approved nanomedicine products," Nanomedicine: Nanotechnology, Biology, and Medicine, vol. 9, no. 1, pp. 1-14, 2013.

[26] S. Swain, P. K. Sahu, S. Beg, and S. M. Babu, "Nanoparticles for cancer targeting: Current and future directions," Current Drug Delivery, vol. 13, no. 8, pp. 1290-1302, 2016.

[27] E. S. Kawasaki and A. Player, "Nanotechnology, nanomedicine, and the development of new, effective therapies for cancer," Nanomedicine: Nanotechnology, Biology, and Medicine, vol. 1, no. 2, pp. 101-109, 2005.

[28] B. Ehdaie, "Application of nanotechnology in cancer research: review of progress in the National Cancer Institute's alliance for nanotechnology," International Journal of Biological Sciences, vol. 3, no. 2, pp. 108-110, 2007.

[29] G. Guerra, "European regulatory issues in nanomedicine," NanoEthics, vol. 2, no. 1, pp. 87-97, 2008.

[30] M. Hofmann-Amtenbrink, H. Hofmann, A. Hool, and F. Roubert, "Nanotechnology in medicine: European research and its implications," Swiss Med Wkly, vol. 144, 2014.

[31] M. Wang and M. Thanou, "Targeting nanoparticles to cancer," Pharmacol Res, vol. 62, pp. 90-99, 2010.

[32] N. Nasongkla, E. Bey, J. Ren et al., "Multifunctional polymeric micelles as cancer-targeted, MRI-ultrasensitive drug delivery systems," Nano Letters, vol. 6, pp. 2427-2430, 2006.

[33] E. Pérez-Herrero and A. Fernández-Medarde, "Advanced targeted therapies in cancer: drug nanocarriers, the future of chemotherapy," Eur J Pharm Biopharm, vol. 93, pp. 52-79, 2015.

[34] R. M. Sawant, J. P. Hurley, S. Salmaso et al., “'SMART” drug delivery systems: double-targeted $\mathrm{pH}$-responsive pharmaceutical nanocarriers," Bioconjug Chem, vol. 17, pp. 943-949, 2006.

[35] N. Kamaly, Z. Xiao, P. M. Valencia, A. F. Radovic-Moreno, and O. C. Farokhzad, "Targeted polymeric therapeutic nanoparticles: design, development and clinical translation," ChemSoc Rev, vol. 41, pp. 2971-3010, 2012.

[36] O. Veiseh, J. W. Gunn, and M. Zhang, "Design and fabrication of magnetic nanoparticles for targeted drug delivery and imaging," Adv Drug Deliv Rev, vol. 62, pp. 284-304, 2010.

[37] J. D. Byrne, T. Betancourt, and L. Brannon-Peppas, "Active targeting schemes for nanoparticle systems in cancer therapeutics," Advanced Drug Delivery Reviews, vol. 60, no. 15, pp. 1615-1626, 2008. 
[38] L. M. Bareford and P. W. Swaan, "Endocytic mechanisms for targeted drug delivery," Advanced Drug Delivery Reviews, vol. 59, no. 8, pp. 748-758, 2007.

[39] K. Cho, X. U. Wang, S. Nie, and D. M. Shin, “Therapeutic nanoparticles for drug delivery in cancer," Clin Cancer Res, vol. 14, pp. 1310-1316, 2008.

[40] S. Bamrungsap, Z. Zhao, T. Chen et al., "Nanotechnology in therapeutics: a focus on nanoparticles as a drug delivery system," Nanomedicine, vol. 7, no. 8, pp. 1253-1271, 2012.

[41] S. E. McNeil, Unique Benefits of Nanotechnology to Drug Delivery and Diagnostics, Humana Press, 2011.

[42] M. S. Surapaneni, S. K. Das, and N. G. Das, "Designing Paclitaxel drug delivery systems aimed at improved patient outcomes: current status and challenges," ISRN pharmacology, 2012.

[43] J. H. Park, G. Saravanakumar, K. Kim, and I. C. Kwon, "Targeted delivery of low molecular drugs using chitosan and its derivatives," Adv Drug Deliv Rev, vol. 62, pp. 28-41, 2010.

[44] Y. Li, Qi. XR, Y. Maitani, and T. Nagai, "PEG-PLA di block copolymer micelle-like nanoparticles as all-trans-retinoic acid carrier: in vitro and in vivo characterizations," Nanotechnology, vol. 20, 2009, PEGPLA di block copolymer micelle-like nanoparticles as all-trans-retinoic acid carrier: in vitro and in vivo characterizations.

[45] V. P. Torchilin, "Recent advances with liposomes as pharmaceutical carriers," Nature Reviews Drug Discovery, vol. 4, no. 2, pp. 145-160, 2005.

[46] L. Mu and S. S. Feng, "A novel controlled release formulation for the anticancer drug paclitaxel (Taxol): PLGA nanoparticles containing vitamin E TPGS," Journal of Controlled Release, vol. 86, no. 1, pp. 33-48, 2003.

[47] U. S. Sharma, S. V. Balasubramanian, and R. M. Straubinger, "Pharmaceutical and physical properties of paclitaxel (taxol) complexes with cyclodextrins," Journal of Pharmaceutical Sciences, vol. 84, no. 10, pp. 1223-1230, 1995.

[48] D. J. Gary, N. Puri, and Y.-Y. Won, "Polymer-based siRNA delivery: Perspectives on the fundamental and phenomenological distinctions from polymer-based DNA delivery," Journal of Controlled Release, vol. 121, no. 1-2, pp. 64-73, 2007.

[49] M. Dash, F. Chiellini, R. M. Ottenbrite, and E. Chiellini, "Chitosan-a versatile semi-synthetic polymer in biomedical applications," Progress in Polymer Science, vol. 36, no. 8, pp. 9811014, 2011.

[50] J. M. Rabanel, V. Aoun, I. Elkin, M. Mokhtar, and P. Hildgen, "Drug-loaded nanocarriers: Passive targeting and crossing of biological barriers," Current Medicinal Chemistry, vol. 19, no. 19, pp. 3070-3102, 2012.

[51] L. N. Patel, J. L. Zaro, and W. C. Shen, "Cell penetrating peptides: intracellular pathways and pharmaceutical perspectives," Pharm. Res, vol. 24, pp. 1977-1992, 2007.

[52] D. D. Lasic, "Novel applications of liposomes", Trends in Biotechnology, vol. 16, no. 7, pp. 307-321, 1998.

[53] B. T. Griffin and C. M. O’Driscoll, “Opportunities and challenges for oral delivery of hydrophobic versus hydrophilic peptide and protein-like drugs using lipid-based technologies," Therapeutic Delivery, vol. 2, no. 12, pp. 1633-1653, 2011.

[54] V. J. Wacher, L. Salphati, and L. Z. Benet, "Active secretion and enterocytic drug metabolism barriers to drug absorption," Advanced Drug Delivery Reviews, vol. 46, no. 1-3, pp. 89-102, 2001.
[55] V. J. Wacher, L. Salphati, and L. Z. Benet, "Active secretion and enterocytic drug metabolism barriers to drug absorption," Advanced Drug Delivery Reviews, vol. 20, no. 1, pp. 99-112, 1996.

[56] J. Rautio, H. Kumpulainen, T. Heimbach et al., "Prodrugs: design and clinical applications," Nature Reviews Drug Discovery, vol. 7, no. 3, pp. 255-270, 2008.

[57] N. Cao and S.-S. Feng, "Doxorubicin conjugated to d- $\alpha$ tocopheryl polyethylene glycol 1000 succinate (TPGS): Conjugation chemistry, characterization, in vitro and in vivo evaluation," Biomaterials, vol. 29, no. 28, pp. 3856-3865, 2008.

[58] Z. Zhang, L. Mei, and S.-S. Feng, "Paclitaxel drug delivery systems," Expert Opinion on Drug Delivery, vol. 10, no. 3, pp. 325-340, 2013.

[59] J. Gong, M. Chen, Y. Zheng, S. Wang, and Y. Wang, "Polymeric micelles drug delivery system in oncology," Journal of Controlled Release, vol. 159, no. 3, pp. 312-323, 2012.

[60] D. S. Kohane, "Microparticles and nanoparticles for drug delivery," Biotechnology and Bioengineering, vol. 96, no. 2, pp. 203-209, 2007.

[61] A. Chaudhary, U. Nagaich, N. Gulati, V. K. Sharma, R. L. Khosa, and M. U. Partapur, "Enhancement of solubilization and bioavailability of poorly soluble drugs by physical and chemical modifications: a recent review," J Adv Pharm Educ Res, vol. 2, pp. 32-67, 2012.

[62] A. J. Ten Tije, J. Verweij, W. J. Loos, and A. Sparreboom, "Pharmacological effects of formulation vehicles: Implications for cancer chemotherapy," Clinical Pharmacokinetics, vol. 42, no. 7, pp. 665-685, 2003.

[63] D. Dube, M. Gupta, and S. P. Vyas, "Nanocarriers for drug targeting to macrophages: emerging options for a therapeutic need," P Natl A Sci India B, vol. 82, pp. 151-165, 2012.

[64] P. Couvreur and C. Vauthier, "Nanotechnology: Intelligent design to treat complex disease," Pharmaceutical Research, vol. 23, no. 7, pp. 1417-1450, 2006.

[65] P. Couvreur, L. Roblot-Treupel, M. F. Poupon, F. Brasseur, and F. Puisieux, "Nanoparticles as microcarriers for anticancer drugs," Advanced Drug Delivery Reviews, vol. 5, no. 3, pp. 209-230, 1990.

[66] S. Bisht and A. Maitra, "Dextran-doxorubicin/chitosan nanoparticles for solid tumor therapy", Interdisciplinary Reviews: J Nanomed Nanotechnol, vol. 1, pp. 415-425, 2009.

[67] L. Zhang, F. X. Gu, J. M. Chan, A. Z. Wang, R. S. Langer, and O. C. Farokhzad, "Nanoparticles in medicine: therapeutic applications and developments," Clin Pharmacol Ther, vol. 83, pp. 761-769, 2008.

[68] D. Peer, J. M. Karp, S. Hong, O. C. Farokhzad, R. Margalit, and R. Langer, "Nanocarriers as an emerging platform for cancer therapy," Nature Nanotechnology, vol. 2, no. 12, pp. 751-760, 2007.

[69] M. E. Davis and D. M. Shin, "Nanoparticle therapeutics: an emerging treatment modality for cancer," Nat Rev Drug Discov, vol. 7, pp. 771-782, 2008.

[70] T. M. Allen, "Ligand-targeted therapeutics in anticancer therapy," Nature Reviews Cancer, vol. 2, no. 10, pp. 750-763, 2002.

[71] Q. Zhang, G. Chen, X. Liu, and Q. Qian, "Monoclonal antibodies as therapeutic agents in oncology and antibody gene therapy," Cell Research, vol. 17, no. 2, pp. 89-99, 2007.

[72] A. M. Wu and P. D. Senter, "Arming antibodies: prospects and challenges for immunoconjugates," Nat Biotechnol, vol. 23, pp. 1137-1146, 2005.

[73] Heath. J. R and M. E. Davis, "Nanotechnology and cancer," Annu Rev Med, vol. 59, pp. 251-265, 2008. 
[74] J. A. MacDiarmid and H. Brahmbhatt, "Minicells: Versatile vectors for targeted drug or si/shRNA cancer therapy," Current Opinion in Biotechnology, vol. 22, no. 6, pp. 909-916, 2011.

[75] S. Singh and H. S. Nalwa, "Nanotechnology and health safety-toxicity and risk assessments of nanostructured materials on human health," Journal of Nanoscience and Nanotechnology, vol. 7, no. 9, pp. 3048-3070, 2007.

[76] E. Casals, S. Vázquez-Campos, N. G. Bastús, and V. Puntes, "Distribution and potential toxicity of engineered inorganic nanoparticles and carbon nanostructures in biological systems," TrAC - Trends in Analytical Chemistry, vol. 27, no. 8, pp. 672683, 2008.

[77] N. R. Panyala, E. M. Peña-Méndez, and J. Havel, "Silver or silver nanoparticles: a hazardous threat to the environment and human health?" Journal of Applied Biomedicine, vol. 6, no. 3, pp. 117-129, 2008.

[78] J. Ai, E. Biazar, M. Jafarpour et al., "Nanotoxicology and nanoparticle safety in biomedical designs," International Journal of Nanomedicine, vol. 6, pp. 1117-1127, 2011.

[79] D. Moinard-Checot, Y. Chevalier, S. Briançon, H. Fessi, and S. Guinebretière, "Nanoparticles for drug delivery: Review of the formulation and process difficulties illustrated by the emulsiondiffusion process," Journal of Nanoscience and Nanotechnology, vol. 6, no. 9-10, pp. 2664-2681, 2006.

[80] B. A. Katsnelson, L. I. Privalova, M. P. Sutunkova et al., "Some inferences from in vivo experiments with metal and metal oxide nanoparticles: The pulmonary phagocytosis response, subchronic systemic toxicity and genotoxicity, regulatory proposals, searching for bioprotectors (a self-overview)," International Journal of Nanomedicine, vol. 10, pp. 3013-3029, 2015.

[81] D. Mukherjee, S. G. Royce, S. Sarkar et al., "Modeling in vitro cellular responses to silver nanoparticles," J Toxicol, vol. 2014, Article ID 852890, 13 pages, 2014.

[82] R. Sequeira, A. Genaidy, R. Shell, W. Karwowski, G. Weckman, and S. Salem, "The nano enterprise: A survey of health and safety concerns, considerations, and proposed improvement strategies to reduce potential adverse effects," Human Factors and Ergonomics In Manufacturing, vol. 16, no. 4, pp. 343-368, 2006.

[83] PH. Hoet, I. Brüske-Hohlfeld, and O. V. Salata, "Nanoparticlesknown and unknown health risks," J Nanobiotechnology, vol. 2, no. $1,2004$.

[84] A. Nel, T. Xia, and L. Mädler, "Toxic potential of materials at the nano level," Science, vol. 311, pp. 622-627, 2006.

[85] P. J. Borm, D. Robbins, S. Haubold et al., "The potential risks of nanomaterials: a review carried out for ECETOC," Part Fibre Toxicol, vol. 3, no. 11, 2006.

[86] B. A. Rzigalinski and J. S. Strobl, "Cadmium-containing nanoparticles: perspectives on pharmacology and toxicology of quantum dots," Toxicol Appl Pharmacol, vol. 238, pp. 280-288, 2009.

[87] G. Oberdörster, E. Oberdörster, and J. Oberdörster, "Nanotoxicology: an emerging discipline evolving from studies of ultrafine particles," Environmental Health Perspectives, vol. 113, no. 7, pp. 823-839, 2005.

[88] J. Lovrić, S. J. Cho, F. M. Winnik, and D. Maysinger, "Unmodified cadmium telluride quantum dots induce reactive oxygen species formation leading to multiple organelle damage and cell death," Chemistry and Biology, vol. 12, no. 11, pp. 1227-1234, 2005.

[89] N. Chen, Y. He, Y. Su et al., “The cytotoxicity of cadmium-based quantum dots," Biomaterials, vol. 33, pp. 1238-1244, 2012.
[90] Y. Su, M. Hu, C. Fan et al., "The cytotoxicity of CdTe quantum dots and the relative contributions from released cadmium ions and nanoparticle properties," Biomaterials, vol. 31, no. 18, pp. 4829-4834, 2010.

[91] F. R. Khan, G. M. Kennaway, M.-N. Croteau et al., "In vivo retention of ingested au NPs by daphnia magna: No evidence for trans-epithelial alimentary uptake," Chemosphere, vol. 100, pp. 97-104, 2014.

[92] C. S. Yah, "The toxicity of gold nanoparticles in relation to their physiochemical properties," Biomedical Research, vol. 24, no. 3, pp. 400-413, 2013.

[93] S. Kundu, S. Lau, and H. Liang, "Shape-controlled catalysis by cetyltrimethylammonium bromide terminated gold nanospheres, nanorods, and nanoprisms," Journal of Physical Chemistry C, vol. 113, no. 13, pp. 5150-5156, 2009.

[94] W. H. Suh, K. S. Suslick, G. D. Stucky, and Y. H. Suh, "Nanotechnology, nanotoxicology, and neuroscience," Prog Neurobiol, vol. 87, pp. 133-170, 2009.

[95] A. A. Shvedova, V. Castranova, E. R. Kisin et al., "Exposure to carbon nanotube material: assessment of nanotube cytotoxicity using human keratinocyte cells," Journal of Toxicology and Environmental Health. Part A, vol. 66, no. 20, pp. 1909-1926, 2003.

[96] Y. Zhang, S. F. Ali, E. Dervishi et al., "Cytotoxicity effects of graphene and single-wall carbon nanotubes in neural phaeochromocytoma-derived pc12 cells," ACS Nano, vol. 4, no. 6, pp. 3181-3186, 2010.

[97] M. A. Dobrovolskaia, P. Aggarwal, J. B. Hall, and S. E. McNeil, "Preclinical studies to understand nanoparticle interaction with the immune system and its potential effects on nanoparticle biodistribution," Molecular Pharmaceutics, vol. 5, no. 4, pp. 487495, 2008.

[98] S. Mazumder, D. Sarkar, and I. K. Puri, "Nanotechnology commercialization: prospects in India," J Mater Sci Nanotechnol, vol. 2, no. 2, 2014.

[99] G. Oberdörster, A. Maynard, K. Donaldson et al., "Principles for characterizing the potential human health effects from exposure to nanomaterials: elements of a screening strategy," Part Fibre Toxicol, vol. 2, no. 8, 2005.

[100] D. Thassu, Y. Pathak, and M. Deleers, "Nanoparticulate DrugDelivery Systems," in Nanoparticulate Drug Delivery Systems, pp. 1-131, CRC Press, 2007.

[101] N. A. Ochekpe, P. O. Olorunfemi, and N. C. Ngwuluka, "Nanotechnology and drug delivery part 2: nanostructures for drug delivery," Tropical Journal of Pharmaceutical Research, vol. 8, no. 3, pp. 275-287, 2009.

[102] W. M. Pardridge, "Blood-brain barrier delivery," Drug Discovery Today, vol. 12, no. 1-2, pp. 54-61, 2007.

[103] Y. Chen and L. Liu, "Modern methods for delivery of drugs across the blood-brain barrier," Adv Drug Deliv Rev, vol. 64, pp. 640-665, 2012.

[104] R. L. Oliver, "Whence consumer loyalty?" Journal of Marketing, vol. 63, pp. 33-44, 1999.

[105] M. W. Kreuter, S. N. Lukwago, D. C. Bucholtz, E. M. Clark, and V. Sanders-Thompson, "Achieving cultural appropriateness in health promotion programs: targeted and tailored approaches," Health Education \& Behavior, vol. 30, no. 2, pp. 133-146, 2003.

[106] P. R. Lockman, M. O. Oyewumi, J. M. Koziara, K. E. Roder, R. J. Mumper, and D. D. Allen, "Brain uptake of thiamine-coated nanoparticles," Journal of Controlled Release, vol. 93, no. 3, pp. 271-282, 2003. 
[107] J. M. Koziara, T. R. Whisman, M. T. Tseng, and R. J. Mumper, "In-vivo efficacy of novel paclitaxel nanoparticles in paclitaxelresistant human colorectal tumors," Journal of Controlled Release, vol. 112, no. 3, pp. 312-319, 2006.

[108] J. M. Koziara, P. R. Lockman, D. D. Allen, and R. J. Mumper, "The blood-brain barrier and brain drug delivery," Journal of Nanoscience and Nanotechnology, vol. 6, no. 9-10, pp. 2712-2735, 2006.

[109] S. B. Tiwari and M. M. Amiji, "A review of nanocarrier-based CNS delivery systems," Curr Drug Deliv, vol. 3, pp. 219-232, 2006.

[110] A. P. Nikalje, "Nanotechnology and its Applications in Medicine," Medicinal Chemistry, vol. 5, no. 2, pp. 81-89, 2015.

[111] T. T. V. Doan and H. K. T. Nguyen, "Study on Minicell Generation of Lactobacillus acidophilus VTCC-B-871 for Drug Delivery," J Appl Pharm Sci, vol. 3, pp. 33-36, 2013.

[112] H. K. T. Nguyen and T. T. V. Doan, "Effects of Carbon Sources on cell differentiation of Lactobacillus rhamnosusPN04 and applications," Biochem Pharmacol, vol. 6, pp. 197-203, 2013.

[113] T. H. K. Nguyen, V. T. T. Doan, L. D. Ha, and H. N. Nguyen, "Molecular cloning, Expression of minDGene from Lactobacillus acidophilus VTCC-B-871 and Analyses to Identify Lactobacillus rhamnosus PN04 from Vietnam Hottuynia cordata Thunb," Ind J Microbiol, vol. 53, no. 4, pp. 385-390, 2013.

[114] P. A. J. Boer, W. R. Cook, and L. I. Rothfield, "Bacterial cell division," Annu Rev Genet, vol. 24, pp. 249-274, 1990.

[115] J. Lutkenhaus and S. G. Addinall, "Bacterial cell division and the Z ring," Annu Rev Biochem, vol. 66, 1997.

[116] A. Flemming, "Minicells deliver lethal load to tumours," Nature Reviews Drug Discovery, vol. 6, no. 7, pp. 519-519, 2007.

[117] H. Brahmbhatt and J. MacDiarmid, U.S. Patent Application No. 13/711, p. 848, 2012.

[118] V. Gujrati, S. Kim, S.-H. Kim et al., "Bioengineered bacterial outer membrane vesicles as cell-specific drug-delivery vehicles for cancer therapy," ACS Nano, vol. 8, no. 2, pp. 1525-1537, 2014.

[119] M. Slater and M. Schaechter, "Control of cell division in bacteria," Bacteriol Rev, vol. 38, 1974.

[120] M. J. Giacalone, J. C. Zapata, N. L. Berkley et al., "Immunization with non-replicating E. coli minicells delivering both protein antigen and DNA protects mice from lethal challenge with lymphocytic choriomeningitis virus," Vaccine, vol. 25, no. 12, pp. 2279-2287, 2007.

[121] J. Delcour, T. Ferain, M. Deghorain, E. Palumbo, and P. Hols, "The biosynthesis and functionality of the cell-wall of lactic acid bacteria," Antonie van Leeuwenhoek, International Journal of General and Molecular Microbiology, vol. 76, no. 1-4, pp. 159$184,1999$.

[122] P. Schär-Zammaretti and J. Ubbink, "The Cell Wall of Lactic Acid Bacteria: Surface Constituents and Macromolecular Conformations," Biophysical Journal, vol. 85, no. 6, pp. 4076-4092, 2003.

[123] S. J. Tonn and J. E. Gander, "Biosynthesis of polysaccharides by prokaryotes," Annu Rev Microbiol, vol. 33, pp. 169-199, 1979.

[124] N. Mozes and S. Lortal, "X-ray photoelectron spectroscopy and biochemical analysis of the surface of Lactobacillus helveticus ATCC 12046," Microbiology, vol. 141, no. 1, pp. 11-19, 1995.

[125] D. Frenkel and B. Smit, Understanding Molecular Simulation: From Algorithms to Applications, vol. 1, Academic Press, 2001.

[126] H. Engelhardt and J. Peters, "Structural research on surface layers: A focus on stability, surface layer homology domains, and surface layer-cell wall interactions," Journal of Structural Biology, vol. 124, no. 2-3, pp. 276-302, 1998.

[127] J. A. MacDiarmid, N. B. Amaro-Mugridge, J. Madrid-Weiss et al., "Sequential treatment of drug-resistant tumors with targeted minicells containing siRNA or a cytotoxic drug," Nature Biotechnology, vol. 27, no. 7, pp. 643-651, 2009.

[128] B. J. Solomon, J. Desai, M. Rosenthal et al., "A first-time-inhuman phase i clinical trial of bispecific antibody-targeted, paclitaxel-packaged bacterial minicells," PLoS ONE, vol. 10, no. 12, Article ID e0144559, 2015.

[129] J. R. Whittle, J. D. Lickliter, H. K. Gan et al., "First in human nanotechnology doxorubicin delivery system to target epidermal growth factor receptors in recurrent glioblastoma," Journal of Clinical Neuroscience, vol. 22, no. 12, pp. 1889-1894, 2015. 

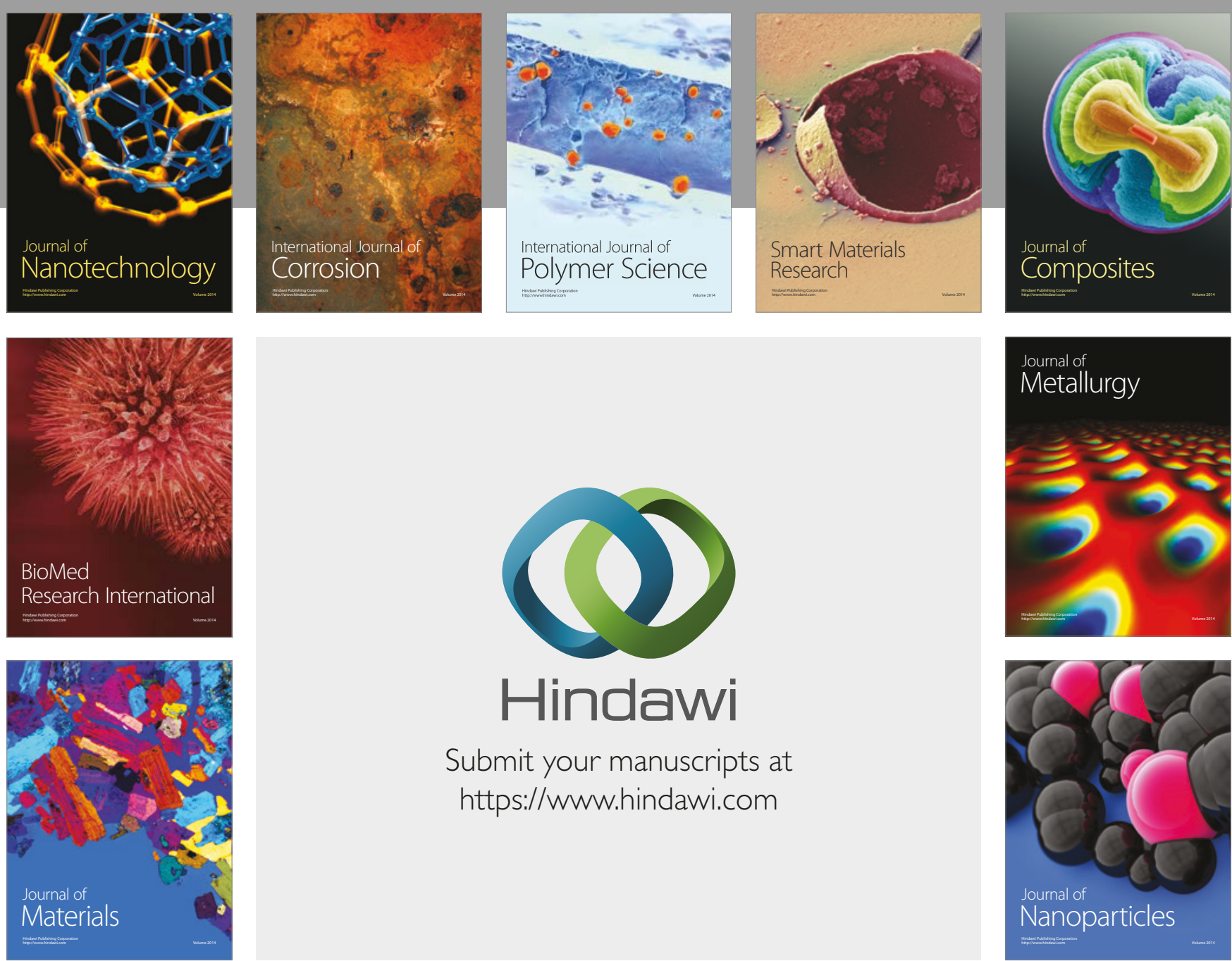

\section{Hindawi}

Submit your manuscripts at

https://www.hindawi.com
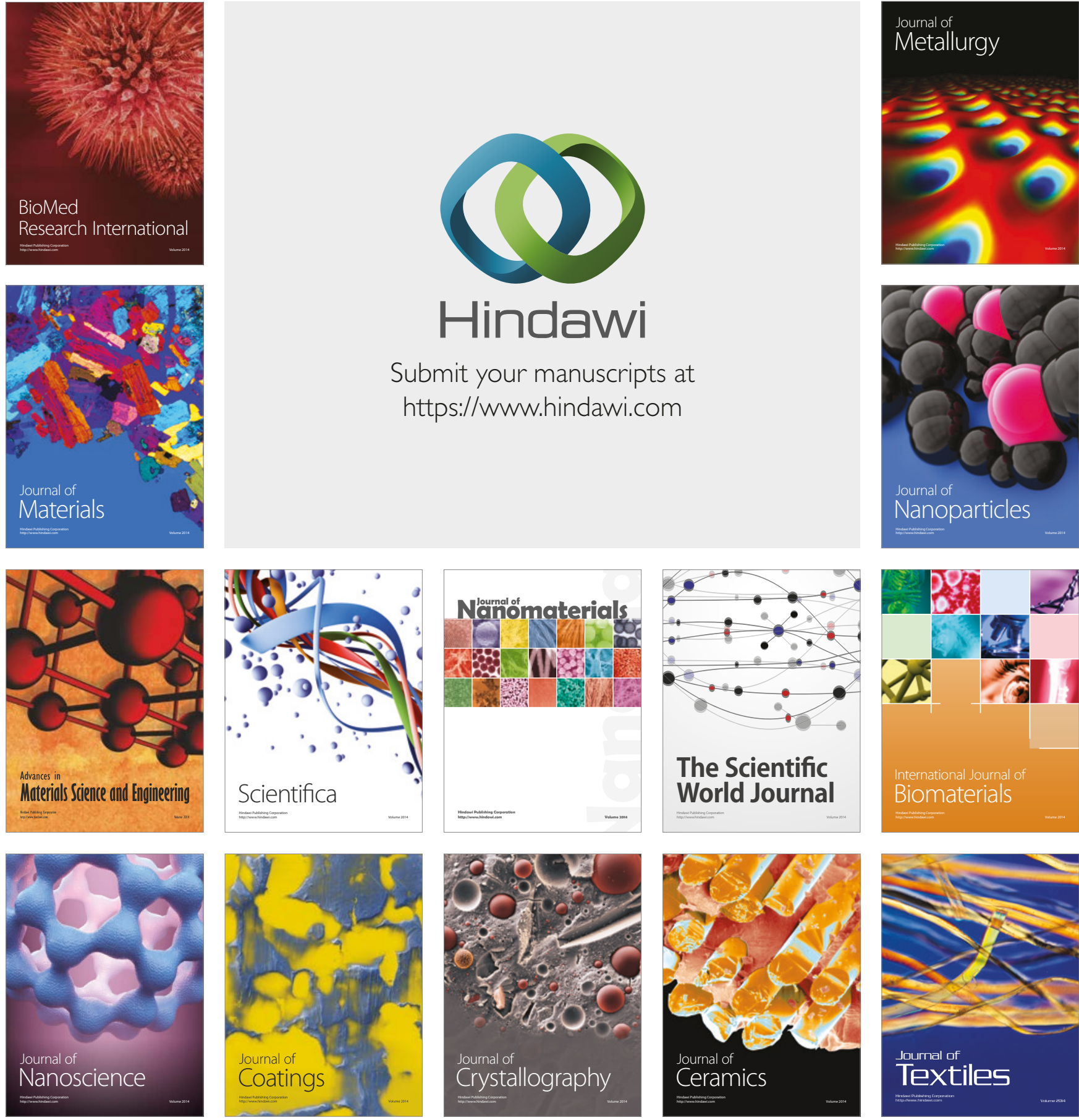

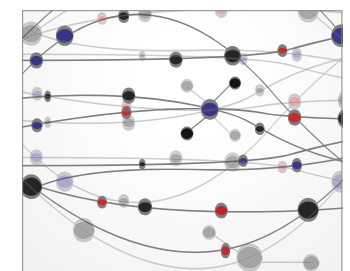

The Scientific World Journal
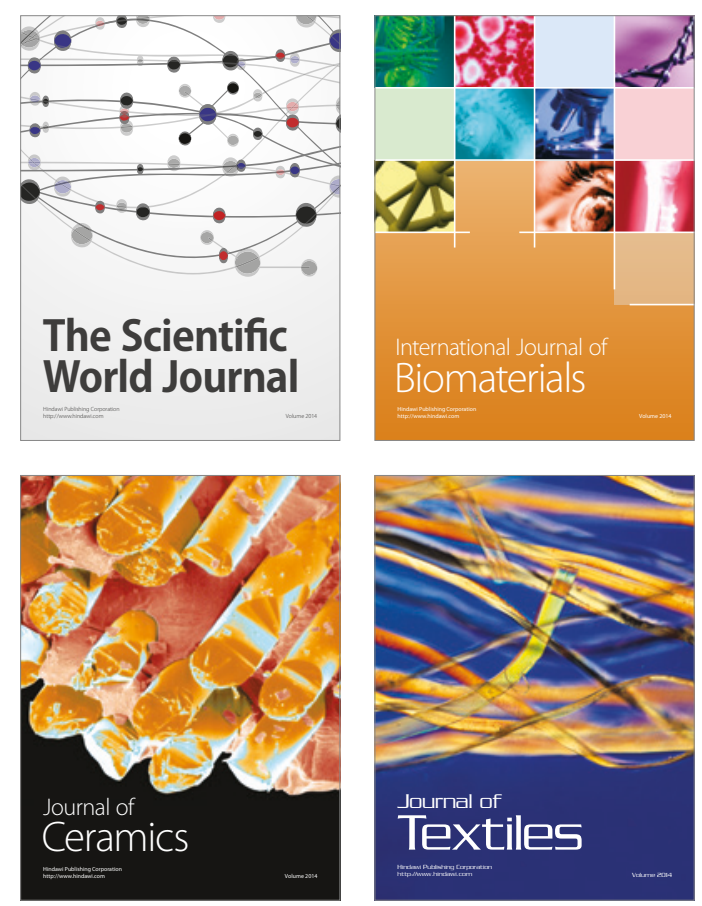